\title{
SITE SUITABILITY ANALYSIS AND ROUTE OPTIMIZATION FOR SOLID WASTE DISPOSAL IN YOLA TOWN, ADAMAWA STATE NIGERIA.
}

\author{
${ }^{1}$ Emmanuel, F. D., ${ }^{1}$ Musa, A. A. and ${ }^{2}$ Nanpon, Z. \\ fimbaemma77@yahoo.com, drabumusa@yahoo.com, and zitta.nanpon@ futminna.edu.ng \\ ${ }^{1}$ Department of Surveying and Geoinformatics, Modibbo Adama University of Technology, \\ Yola, Adamawa State, Nigeria. ${ }^{2}$ Department of Surveying and Geoinformatics, Federal \\ University of Technology, Minna, Niger State, Nigeria
}

DOI: http://dx.doi.org/10.4314/sajg.v6i1.8

\begin{abstract}
Solid waste management system is a tedious task that is facing both developing and developed countries. Site Suitability analysis and route optimization for solid waste disposal can make waste management cheap and can be used for sustainable development. However, if the disposal site(s) is/are not sited and handle properly, it can cause environmental pollution and affect public health, hence the application of GIS and Remote Sensing to waste disposal Site Suitability analysis and route optimization for solid waste in Yola town. Different factors or criteria were considered in relation to solid waste disposal sites. In order to achieve the aim of this paper, the Boolean logic was used, where suitable areas were assigned value 1 and unsuitable area were assigned 0 for each of the criteria. The Boolean images were overlaid to produce the suitability map. The result of the suitability analysis gave a total of six sites out of which three met the criteria of size having an area of $612.75 \mathrm{Ha}$ which constitute $6.12 \%$ of the total area of the study area. The optimized route were generated connecting the proposed disposal site which are truck 1, truck 2, and truck 3 with distances of $19.65 \mathrm{~km}, 17.16 \mathrm{~km}$ and $22.11 \mathrm{~km}$ respectively. It is recommended that remote sensing and GIS can be used in increasing efficiency of solid waste management in an urban settlement.
\end{abstract}

Keywords: Solid waste, Suitable site, Route Optimization, GIS, Remote Sensing and Disposal site.

\subsection{Introduction}

Solid Waste Management is considered as one of the serious environmental problem facing both developed and developing countries like Nigeria. However, Solid Waste is referred to as any garbage, refuse, sludge from a waste water treatment plant, water supply treatment plant or air dried material, including solid, liquid, semi-solid or contained gaseous material as a result of industrial, commercial, mining and agricultural operations and also from various community activities (USEPA, 2005; Munier, 2005). Moreover, Solid waste disposal is of enormous concern in developing countries across the world, as poverty, population growth, and high urbanization rates combine with poor funding has led to poor Waste Management (UNDP, 2004). The rapid growth of urban, agricultural and industrial activities due to population explosion has led to the 
generation of huge amounts of solid and liquid waste that pollute the environment and destroy natural resources (UNEP, 2005).

The Waste Management in Yola Town has been facing problems starting from the collection to the final disposal site due to the increased in waste generation, unplanned facilities, increase in population and poor management of waste bins. Moreover, the open dumping system is currently practiced which causes environmental degradation and public health problems to the populace in the study area. These resulted from non-adherence to the various criteria for suitable site selection. The open dump sites along Yolde Pate road and Mbamba are been mostly utilized, which are known to pose a significant risk to the public. Aljaradin and Persson (2012) as cited in Salamatu et al. (2016) stated that open dumps contribute a considerable amount of methane gas into the atmosphere increases global warming. Solid waste management also includes transportation; therefore, optimizing the process of managing waste is an issue that needs to be considered, particularly in road routing for the Waste collection and transportation.

Geographic Information System (GIS) as a management tool is capable of providing effective handling, display and manipulation of both geographic and spatial information. According to Bodin and Golden, (1981), the collection and transportation of Solid Waste often accounts for a considerable percentage of the total amount budgeted for Solid Waste Management. Ashtashil and Raisoni, (2011), use a Network Analyst to estimate interrelations between the dynamic factors, like network traffic changes in the area under study and to produce optimized solutions.

A suitable disposal site must have environmental safety criteria and attributes that will enable the wastes to be isolated so that there is no risk posed to humans, animals and the environment (Mujibor et al., 2008). The criteria for site suitability analysis cuts across natural, physical characteristics, socioeconomic, ecological and land-use factors (Mujibor et al., 2008; Michael and Julius, 2013). Bagchi, (2004) asserted that, the waste disposal site should not be placed within water resources areas in order to protect it from contamination; closer to the existing road network for accessibility and cost related issues in transporting the waste from generation or transfer station to the site; and siting waste disposal sites on a less steep surface would reduce cost of locating the disposal facility. Soil spatial and attribute information is required for evaluating protective functions of soil layers for many environmental modeling and applications. 
The application of these technologies has proven excellently in solving environmentally related issues as seen in Rahman et al. (2008), Yadav (2013), Onuigbo and Bello (2014), Nishanth et al. (2010), Ebistu and Minale (2013), Mânoiu et al. (2013), Ahsan et al. (2014), Chimote and Bhabhulkar (2012), Ogwueleka (2009), Ramkrishnaiah et al. (2014) and Musa (2012). In this research, the suitable site and optimal routes for solid waste collection and disposal were determined using GIS and Remote sensing techniques. This leads to high reduction of risk of environmental pollution and public health hazards as a result of indiscriminate disposal of waste and it also reduces the cost in wear and tear and fuel consumption of the refuse van by virtue of determining the shortest and optimal routes to evacuate the refuse. The time spent in refuse evacuation is also reduced thereby reducing the man hours of workers leading to increased efficiency. Furthermore, proper Solid Waste Management and disposal improve the aesthetic of the environment and a community devoid of any form of health hazards associated with Solid Waste such as cholera, typhoid, malaria, etc.

\subsection{Study Area}

Yola town is the traditional seat of Lamido of Adamawa which lies between $09^{\circ} 10^{\prime}$ to $09^{\circ} 14^{\prime} \mathrm{N}$ and $012^{\circ} 26^{\prime}$ to $012^{\circ} 31^{\prime} \mathrm{E}$ with $174 \mathrm{~m}$ above mean sea level. Yola town is closer to Jimeta the Administration and commercial center of the Adamawa state. Yola town is divided into eight wards: Bole-Yolde pate, Bako, Mbamoi, Makama A, Makama B, Toungo, Addarawo and Mbamba wards. The population is about 246,068 and a density of 226.2 persons per square kilometer (1991 census). It lies within the Sudan savannah zone. Yola is described as the sunshine state with minimum temperature of $21^{\circ} \mathrm{C}$ and maximum temperature of $41^{\circ} \mathrm{C}$ and with average annual precipitation of $917 \mathrm{~mm}$. 


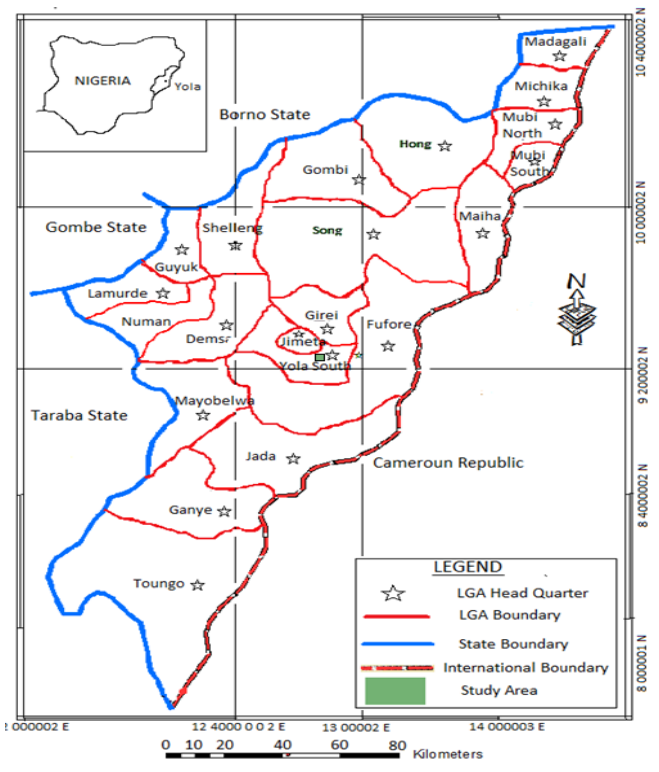

Figure 1: Map of Nigeria showing Adamawa state and Adamawa state showing Yola South L.G.A. source: Adamawa state ministry of Land and Survey, Yola.

\subsection{Materials and Methods}

The hardware included Hp Laptop computer with 2.00 GB of RAM and 500 GB HARD disk, a Garmin Hand held Global positioning system and the software used was ESRI's ArcMap 10.1. The Table 1 shows the list of data used in the research. The Geology and Soil maps were scanned, georeferenced and digitized using ArcGIS 10.1 and the root mean square error was found to be 0.00532 .

Table 1: List of Data

\begin{tabular}{|c|c|c|c|}
\hline Data type & Resolution/scale & Date & Source \\
\hline SRTM & $90 \mathrm{~m} \times 90 \mathrm{~m}$ & $23 / 06 / 2015$ & USGS \\
\hline Street guide map & $1: 25,000$ & 1989 & $\begin{array}{l}\text { Adamawa State Min. } \\
\text { of Land \& Survey, } \\
\text { Yola }\end{array}$ \\
\hline $\begin{array}{l}\text { Geology and Soil } \\
\text { maps }\end{array}$ & $1: 1,000,000$ & 1990 & $\begin{array}{l}\text { Geological Survey Agency, } \\
\text { Yola }\end{array}$ \\
\hline LANDSAT 8 & $30 \mathrm{~m} \times 30 \mathrm{~m}$ & $04 / 05 / 2015$ & USGS \\
\hline IKONOS image & $0.8 \mathrm{~m}$ & $20 / 06 / 2015$ & Google Earth \\
\hline $\begin{array}{l}\text { Waste bin } \\
\text { Location }\end{array}$ & - & $11 / 07 / 2015$ & Field Survey \\
\hline Well Depth & - & $15 / 08 / 2015$ & Field Survey \\
\hline
\end{tabular}




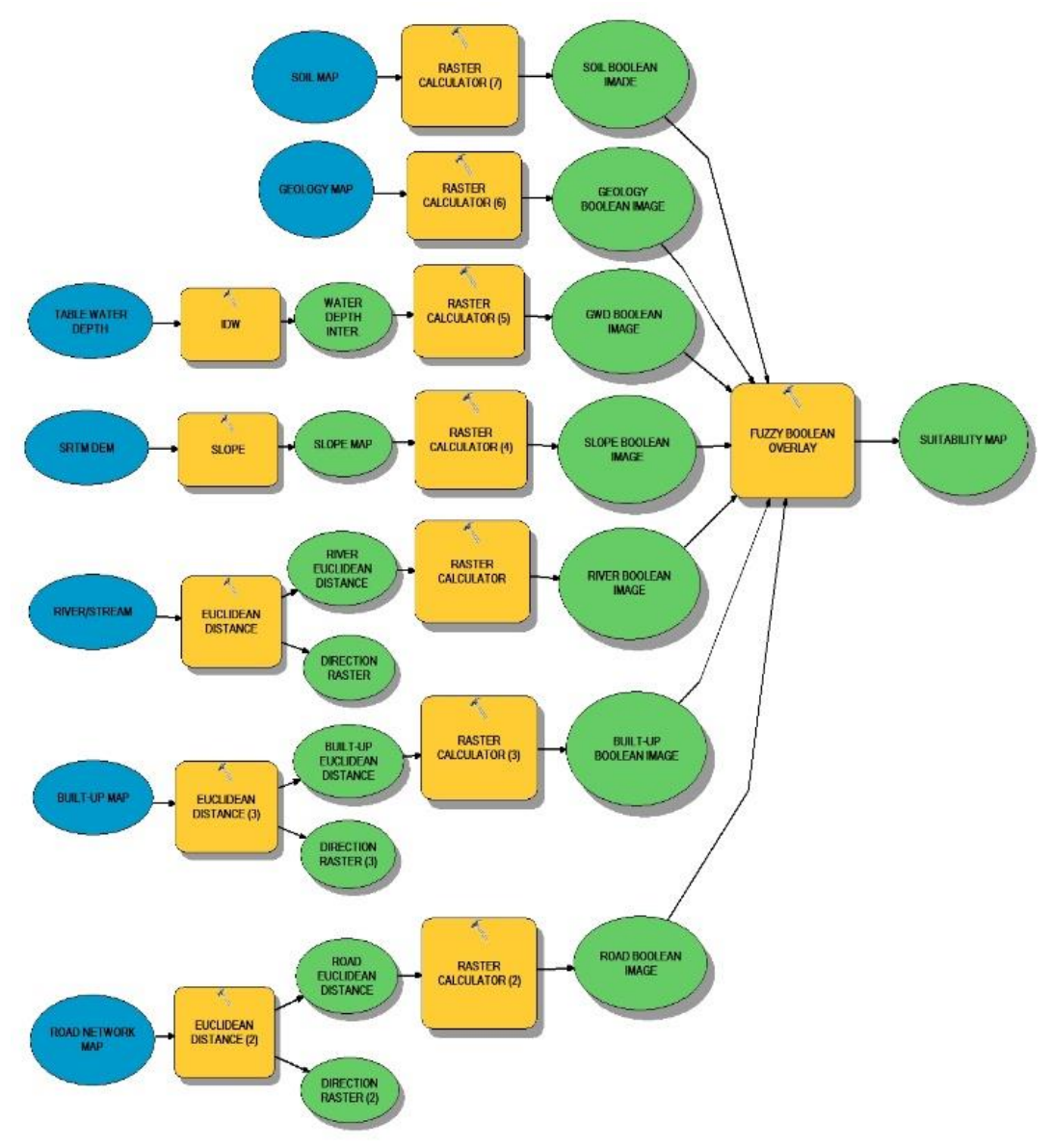

Figure 2: Workflow of Methodology for suitability analysis

The waste bins locations were mapped using Handheld GPS. Their coordinates were plotted in ArcGIS 10.1 and overlaid on the digitized road network from the IKONOS image. The suitability analysis was run as shown in Figure 2. The Boolean images of the various dataset were generated using Raster Calculator under Spatial Analyst tools in ArcGIS software. The Suitable site for Waste disposal should be located on areas with Groundwater depth greater than $5 \mathrm{~m}$ is assigned value 1 otherwise 0 so as to minimize the probability of Groundwater contamination or pollution and also on a terrain with Slope less than $20^{\circ}$, assigned value 1 otherwise 0 . The Site should be at least $100 \mathrm{~m}$ from a major Road, $500 \mathrm{~m}$ from a River or Stream and settlement. These were buffered at specified distances; areas falling within the buffered zones are not suitable hence assign value 0 otherwise 1 (suitable). Clayed textured Soil is advisable which is impermeable to leachate. The size of the soil pores is of great importance with regards to the rate of infiltration and to the rate of percolation. Pore size and the number of pores closely related to soil texture and structure and also influence soil permeability. Usually, the finer the soil texture, the slower the 
permeability. So, the average permeability for different soil textures in $\mathrm{cm} /$ hour is as follows: sand $5.0 \mathrm{~cm} /$ hour; Sandy loam $2.5 \mathrm{~cm} /$ hour; Loam $1.3 \mathrm{~cm} /$ hour; clay loam $0.8 \mathrm{~cm} /$ hour silty clay $0.25 \mathrm{~cm} /$ hour and Clay $0.05 \mathrm{~cm} /$ hour. Hence, clay soil is suitable and assigns value 1 otherwise 0. It is necessary to locate a Waste Disposal Site on Geology with impermeable Strata and consolidated material which do not allow movement of leachate and hence minimize the risk of Groundwater contamination from the Waste Disposal site, (Bagchi, 2004).

ArcGIS Network Analyst was used to determine optimal routes network for solid waste collection and disposal. It has three properties: which includes; stops, routes and barriers. Under 'stop' property, the waste bin point map was loaded. The location of the Zonal Office of the Ministry of Environment (MoE), Yola was inserted manually using 'create network location' tool. Under the 'Route' property, three routes were specified and it was named Truck 1, Truck 2, and Truck 3. The 'Barrier' property was left empty since there is no route that has any barrier. In order to allocate the respective stops to each of the three routes, the properties of each stop was opened; and in the field for the 'Route Name' property, the Route name (i.e. Truck 1, Truck 2 or Truck 3) was inserted. The stops were then rearranged in such a way that the first stop was the Zonal Office MoE, Yola while the last stop was the proposed Waste Disposal Site. Finally, the solve button was clicked to run the analysis. 


\subsection{Results and Discussion}

\subsection{Presentation of Results}

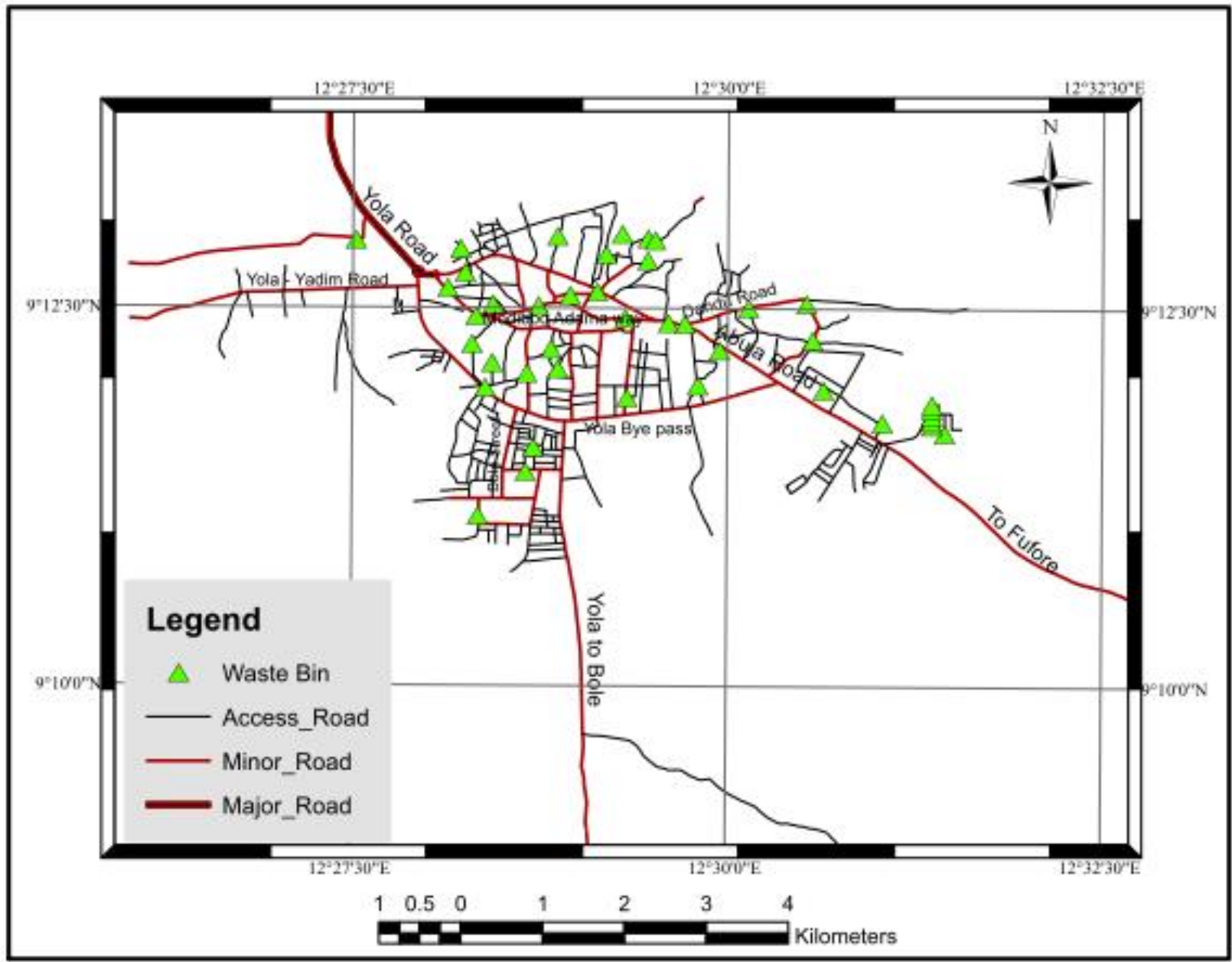

Figure 3: Map of Waste Bins Location

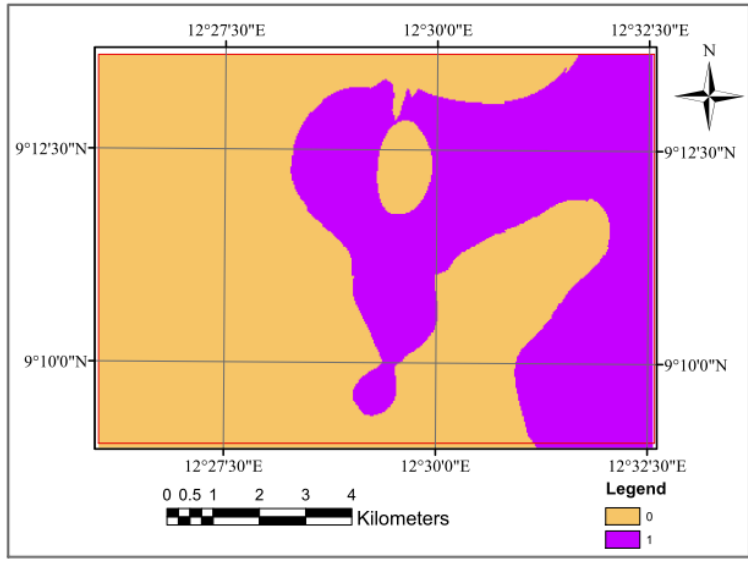

Figure 4: Boolean image of Groundwater depth.

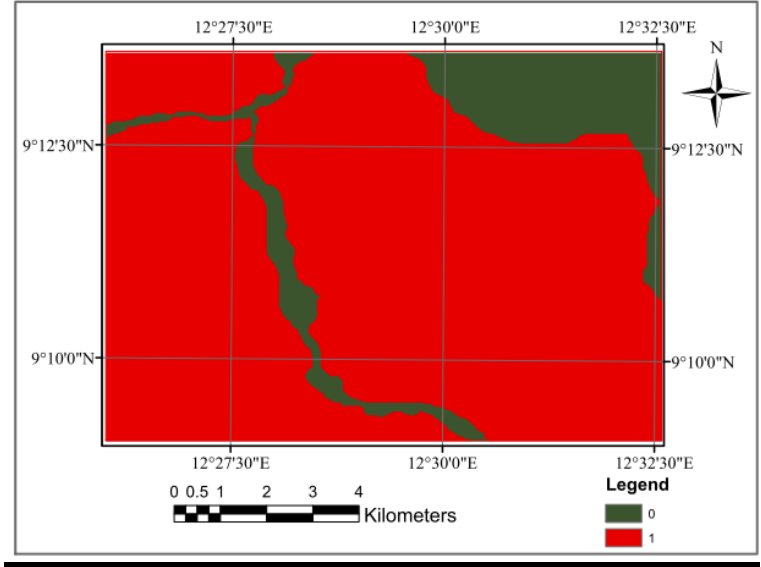

Figure 5: Boolean image of the Geology of the study area. 


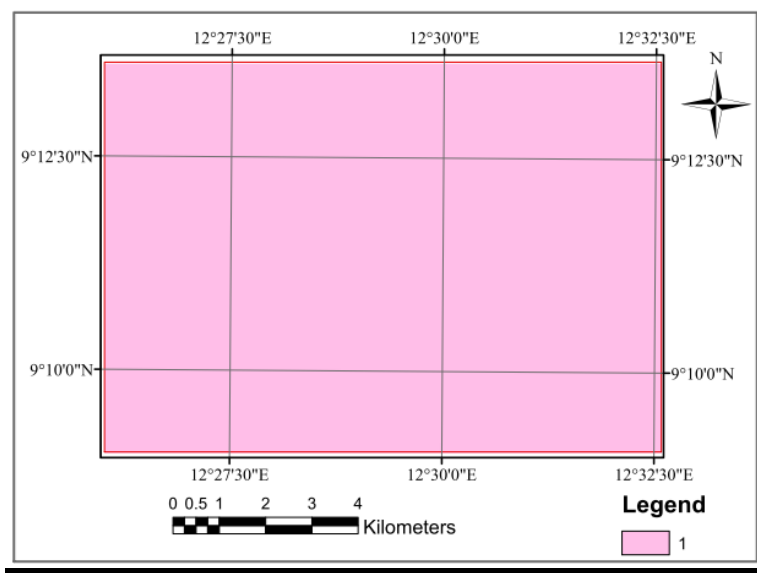

Figure 6: Boolean image of Soil type of the study area.

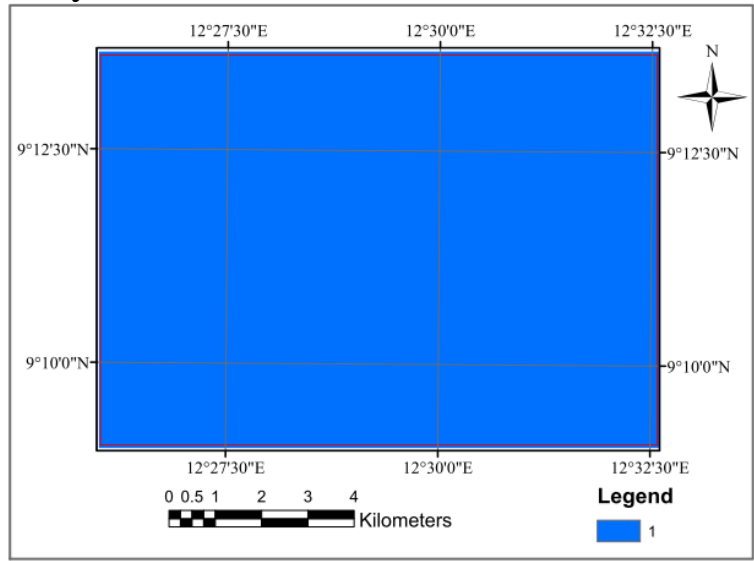

Figure 7: Boolean image of Slope map of the study area.

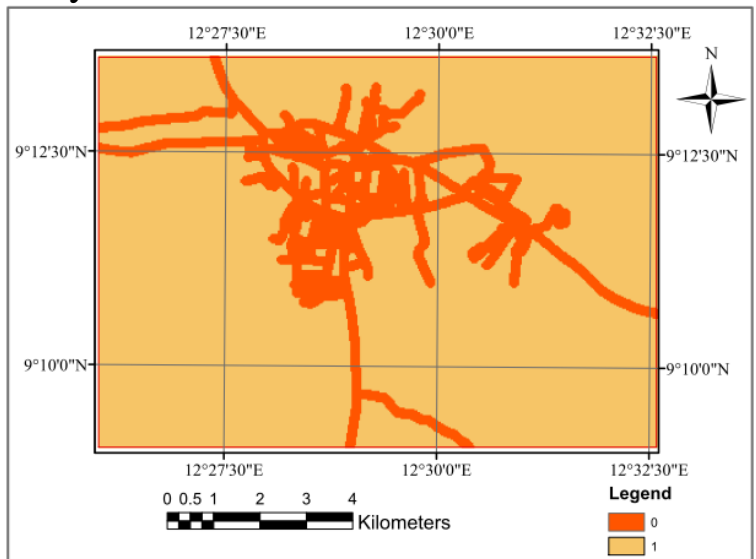

Figure 8: Boolean Image of Road Network of the study area.

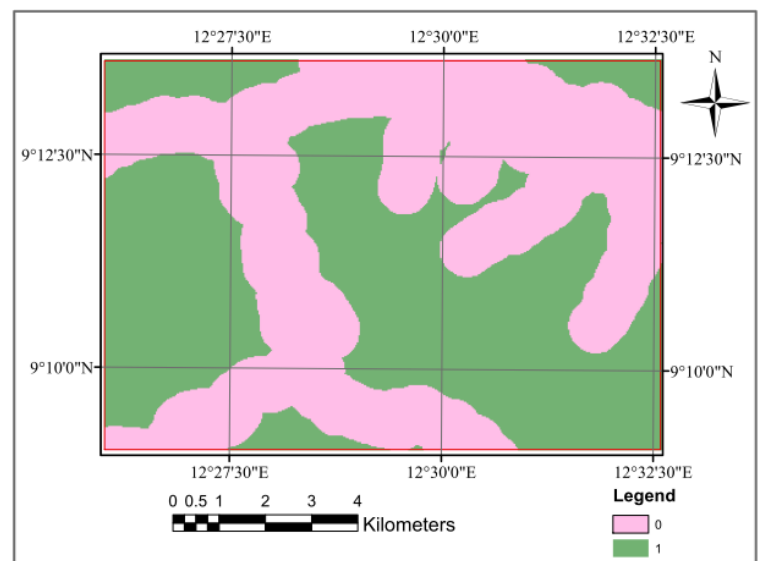

Figure 9: The Boolean Image of Buffered River/Stream of the study area.

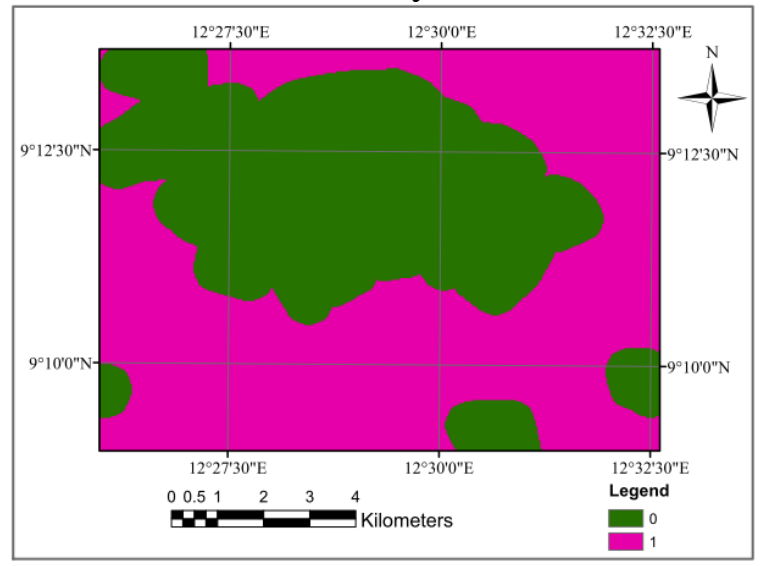

Figure 10: The Boolean images of the Settlements of the study area.

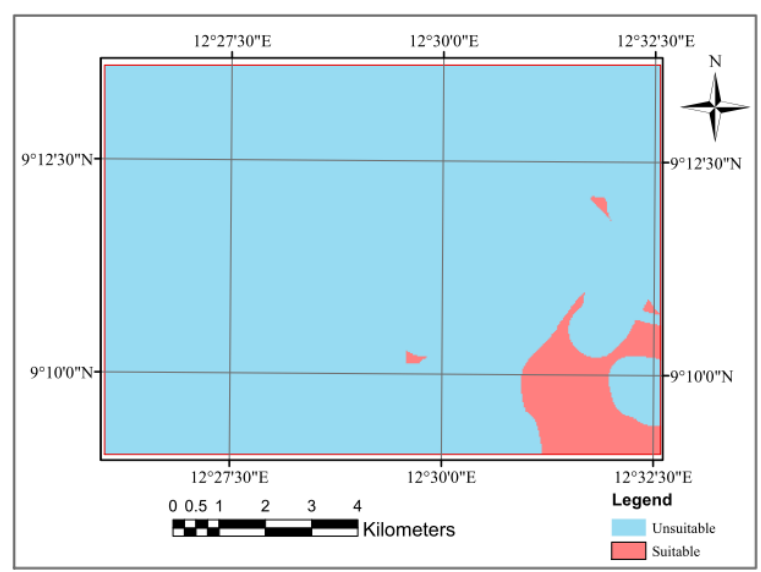

Figure 11: Final Suitability Map of Solid Waste Disposal Site of the study area.

\subsection{Discussion of Results}

Waste Management in Yola Town has been facing problems starting from the collection to the final disposal due to the increased in waste generated, unplanned facilities and poor 
management of waste bins. Moreover, the open dumping system has resulted in environmental and social problems to the populace. The problem resulted from due to non-adherence to the various criteria for suitable site selection.

In this analysis, the consideration of environmental factors such as slope, geology and ground water depth and socio-economic factors such as proximity to settlement, road, river/streams are very important but it is cumbersome, time consuming and expensive. Therefore, the use of GIS as a supporting tool was effectively employed due to its ability to manage spatial and attribute datasets from different sources. This was achieved by defining proximity distance from natural features and settlement areas. ArcGIS software was employed to perform analysis such as buffering, map algebra to produce the Boolean images as shown Figures 4, 5, 6, 7, 8, 9, and 10, and fuzzy overlay to obtain a suitability map of the study area as shown in Figure 11.

The result of suitability analysis shows that five different spots where suitable, mostly around the south east of the study area, viz: North East of Mopol Barracks with total area coverage of $16.88 \mathrm{Ha}$ however, there is no route leading to the area; Mbamba kwana have a total area was found to be $8.44 \mathrm{Ha}$. Another site is located directly across the major road and was also found to be $587.43 \mathrm{Ha}$; others are north of Bole III which is $6.63 \mathrm{Ha}$ which is smaller in size than the required criteria of 7.00Ha. Hence, the site located near Mbamba kwana and the one opposite it has met the criteria which state that the waste disposal site should have an area of $7.00 \mathrm{Ha}$ and above.

The proposed routes as shown in Figure 12 below shows the optimal routes which give directions of the shortest distance between the proposed waste disposal sites and the starting point at the zonal office of the Ministry of Environment (MoE), Yola. The first route i.e. 'Truck 1' have the start point at the zonal office of MoE, Yola to the end point of the proposed waste disposal site travelled through Makama A, Makama B and part of Toungo wards in Yola Town with a total length of $19.65 \mathrm{~km}$ with 15 stops. The second route i.e. 'Truck 2' starting also at MoE, Yola have 12 stops which will traverse through Mbamoi, Toungo and part of Mbamba ward with a total length of $17.16 \mathrm{~km}$. The third route i.e. 'Truck' 3 with 8 stops passes through Bole-Yolde pate ward and Mopol Barracks, Mbamba with a total length of $22.11 \mathrm{~km}$. Since there were no existing routes for waste transportation in the study area, these proposed routes serve as the optimized routes for the waste disposal. Determination of transportation route for waste collection and transportation is very important in order to reduce travel cost and increase efficiency in transferring wastes to the final disposal sites and also it is essential in planning waste management system. 


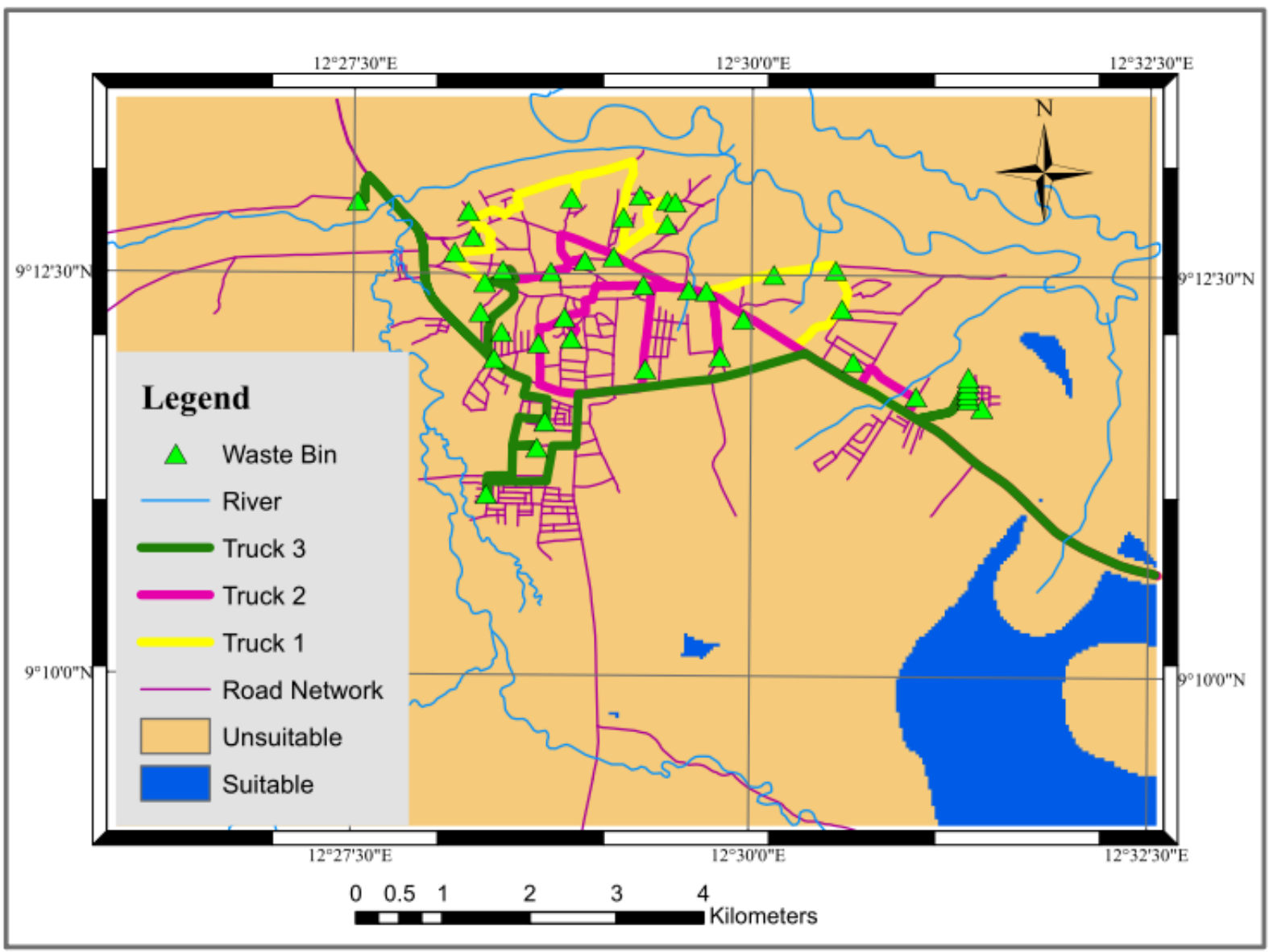

Figure 12: Composite map of Results.

\subsection{Conclusion and Recommendations}

The suitability mapping of the waste disposal site in this research considered seven factors which includes; groundwater depth, geology, soil, slope, Land use / Land cover and proximity to roads, and rivers / streams for proper site selection. The application of GIS for spatial decision making process is an acceptable technique that handles large and conflicting criteria in site selection analysis. In addition, it has been attested that GIS is a powerful tool for route optimization for solid waste collection and disposal was carried out. With the help of GIS, Solid Waste Management can be carried out efficiently and successfully.

A further research is therefore recommended in view of highlighting the increase of parameters and combined techniques for better and sustainable environment and sound public health; also a Differential GPS should be used in tracking the coordinates of the waste bins and a detailed study on the physical and chemical characteristics of soil be carried out; the study should be expanded to take into consideration the increase in population and manpower development so 
that the needs assessment will be projected. It is further recommended that remote sensing and GIS can be used in increasing efficiency of solid waste management in an urban settlement.

\section{References}

Ashtashil V. B. and Raisoni G. H. (2011). Municipal Solid Waste Collection Route Optimized with ArcGIS network analyst. International journal of advanced engineering sciences and technologies vol. no.11, Issue no.1, 202-207.

Bagchi, A. (2004). Design of landfills and integrated solid waste management .New Jersey: John Wiley \& Son Centre for People and Environment. (2010). Landfill recovery and use in Nigeria.

Bodin, L., Golden, B., (1981). Classification in vehicle routing and scheduling Networks 11, pp 97-108.

Chimote, Kedar and Bhabhulkar, Nagpur Astashil (2012). Municipal Solid Waste (MSW) Collection by Geographical Information Systems (GIS), National Conference on Innovative Paradigms in Engineering \& Technology (NCIPET-2012). Proceedings published by International Journal of Computer Applications® (IJCA).

Ebistu, Tirusew Ayisheshim and Minale, Amare Sewnet (2013). Solid Waste Dumping Site Suitability Analysis using Geographic Information Systems (GIS) and Remote Sensing for Bahir Dar Town, North Western Ethiopia. African Journal of Environmental Sciences and Technology. 7(11), pp. 976-989.

Mănoiu, Valentina, Fontanine Iulia, Costache Romulus, Remus Prăvălie,and Iulian Mitof. (2013). Using GIS Techniques for Assessing Waste Landfill placement Suitability. Case study: Prahova County, Romania.Geographia Technica, Vol. 08, No. 2, pp 47 to 56

Michael A. O. and Julius O. F. (2013) Application of GIS of siting and management of solid waste disposal in Akure, Nigeria. Iosr Journal of environmental sciences, toxicology and food technology Vol.4, Issue 2, pp 06-17.

Mujibor R., Kazi R. S. and Ahasanul H. (2008) Suitable sites for urban solid waste disposal using GIS approach in khulna city, Bangladesh Proc. Pakistan AMcadd. .M Sucjii.b 4o5r (R1)a:h1m1-a2n2 .e2t0 a0l8.

Munier, N. (2005). Introduction to Sustainability; Road to a Better Future, Springer, the Netherlands.

Musa A. A. (2012). Application of GIS Network Analysis for proper Management of Refuge Disposal in Jimeta, Nigeria, Adamawa state university Journal of scientific research Vol.2: Issue 2. ISSN: 2251-0702.pp 10-18.

Nishanth,T., Prakash, M.N. and Vijith, H. (2010). Suitable site determination for urban solid waste disposal using GIS and Remote sensing techniques in Kottayam Municipality, India, International Journal of Geomatics and Geosciences, 1:2,197-209. 
Ogwueleka, T.C. (2009) Route optimization for solid waste collection: Onitsha (Nigeria) case study JASEM ISSN 1119-8362, Vol. 13(2) 37 - 40.

Onuigbo, Ifeanyi Chukwudi and Bello, Abdulganiyu Etudaye (2014). Assessment and Selection of Suitable Sites for Solid Waste Disposal using Surveying and Geoinformatics Techniques. International Journal of Engineering Research \& Technology (IJERT) ISSN: 2278-0181, Vol. 3 Issue 8.

Rahman, Mujibor, Ruksana, Kazi Sultana, and Ahasanul Hoque (2008). Suitable Sites for Urban Solid Waste Disposal using GIS Approach in Khulna City, Bangladesh Proc. Paskistan Acad. Sci. 45(1): 11-22

Ramkrishnaiah C. R., Deepika B. V., and Shridhara T. N. (2014), Spatial Decision Support System for Solid Waste Management in Chickmaglur City, IJISET - International Journal of Innovative Science, Engineering \& Technology, Vol. 1 Issue 7. ISSN 2348 - 7968. www.ijiset.com.

Salamatu Kassah, Abdullahi A. Kuta, Nanpon Zitta, Oluibukun G. Ajayi, Semiratu W. Abdullahi and Idris M. Kontagora (2016). Evaluating the spatial distribution of open dumpsites and their effects on the residents in Bosso-Minna, Nigeria. School of Environmental Technology Conference (SETIC, 2016) FUT Minna. pp 517-528

UNEP (2005). Selection, Design and Implementation of Economic Instruments in the Solid Waste Management Sector in Kenya. USA, New York, pp80.

UNEP (2005). Solid Waste Management, Volume II: Regional Overviews and Information Sources. USA, New York, pp334.

United Nations Development Programme (UNDP) (2004). Municipal Solid Waste Management in Developing Countries: A policy Framework. Geneva. Technical paper, 12, Geneva.

United State Environmental Protection Agency (USEPA) 2005. Municipal Solid Waste Basic Facts, http://www.epa.gov/epaoswer/non-hw/muncpl/reduceh.htm. Accessed on 8/12/2014.

Yadav, Surendra Kumar (2013), GIS Based Approach for Site Selection in Waste Management International Journal of Environmental Engineering and Management. ISSN 22311319, Volume 4, Number 5 pp. 507-514. 